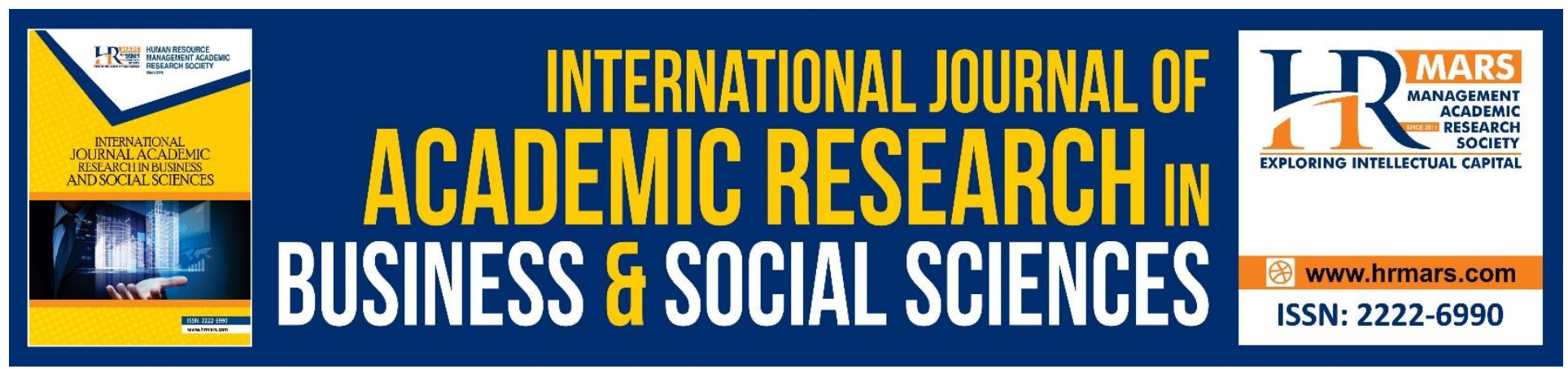

\title{
Shareholder Valuation on a Dollar of Cash Versus Agency Cost: Evidence from High-cash and Low-Cash Level Firm
}

Wei Ni Soh, Zariyawati Mohd Ashhari, Haslinah Muhamad

To Link this Article: http://dx.doi.org/10.6007/IJARBSS/v10-i8/7643

DOI:10.6007/IJARBSS/v10-i8/7643

Received: 04 May 2020, Revised: 06 June 2020, Accepted: 20 July 2020

Published Online: 26 August 2020

In-Text Citation: (Soh, Ashhari, Muhamad, 2020)

To Cite this Article: Soh, W. N., Ashhari, Z. M., Muhamad, H. (2020). Shareholder Valuation on a Dollar of Cash Versus Agency Cost: Evidence from High-cash and Low-Cash Level Firm. International Journal Academic Research in Business and Social Sciences. 10(8), 872-884.

Copyright: @ 2020 The Author(s)

Published by Human Resource Management Academic Research Society (www.hrmars.com)

This article is published under the Creative Commons Attribution (CC BY 4.0) license. Anyone may reproduce, distribute, translate and create derivative works of this article (for both commercial and non-commercial purposes), subject to full attribution to the original publication and authors. The full terms of this license may be seen

at: http://creativecommons.org/licences/by/4.0/legalcode

Vol. 10, No. 8, 2020, Pg. 872 - 884

http://hrmars.com/index.php/pages/detail/IJARBSS

JOURNAL HOMEPAGE

Full Terms \& Conditions of access and use can be found at http://hrmars.com/index.php/pages/detail/publication-ethics 


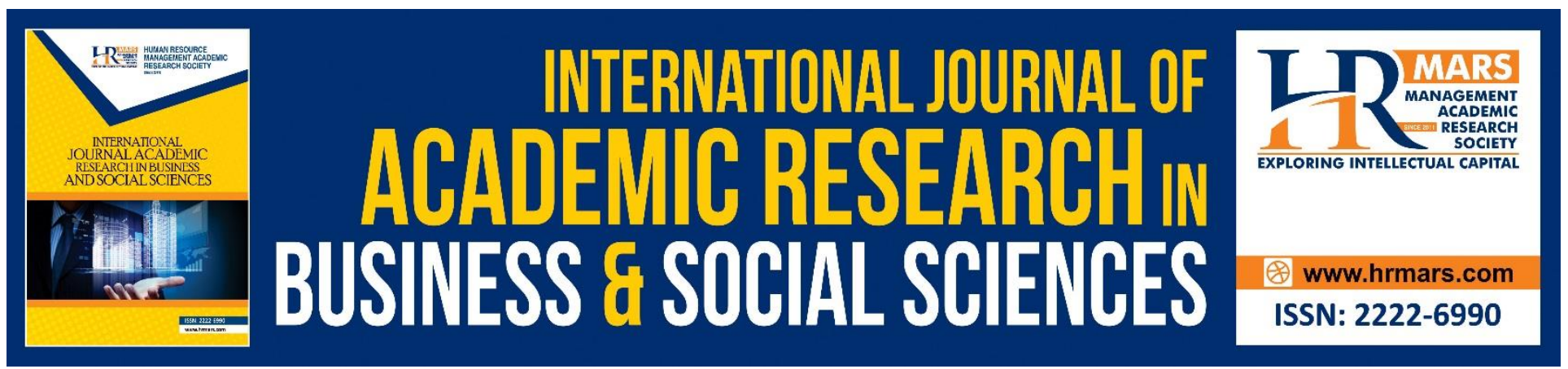

\title{
Shareholder Valuation on a Dollar of Cash Versus Agency Cost: Evidence from High-cash and Low-Cash Level Firm
}

\author{
Wei Ni Soh, Zariyawati Mohd Ashhari, Haslinah Muhamad \\ School of Business and Economics, University Putra Malaysia, Serdang, Malaysia
}

\begin{abstract}
The corporate cash holdings are important when deciding performance and profitability of firms, and also as an extension to shareholders' wealth. The issue of the amount of cash holdings in firms does not solely impact the firms' balance sheets and agency costs. This study argues that the need for holding more cash to reduce default probability is relatively more significant, and should be focused upon rather than agency cost. To compare the agency cost and the value of holing more cash in firm, this study employs the Faulkender \& Wang (2006) methodology in estimating the cash value against excess stock returns, which reflects shareholders' valuation. As the findings, firms with higher cash would generate higher excess stock returns. The shareholders' valuation does not tally with agency cost, showing that shareholders prefer firms to hold less cash. Furthermore, the optimal cash level is not significantly related with shareholders' valuation.
\end{abstract}

Keywords: Agency Conflict, Cash Holdings, Firm Performance.

\section{Introduction}

Cash holdings are liquid assets that provide sufficient liquidity levels for corporations to meet daily operational activities, such as interest due on short-term debt financing, as well as positioning for positive investment opportunities. The role of cash in minimizing the opportunity cost per dollar is a pertinent issue discussed in the trade-off model (Opler et al., 2001). In general, corporations hold excessive cash in the balance sheet for precautionary and liquidity motives (Keynes, 1936). The precautionary motive for holding excessive cash is to provide solutions for an emergency occurring that may impact daily operational activities. Corporate managers prefer to hold more cash reserves when credit risk is high as a precautionary motive (Acharya et al., 2011). However, liquidity motive is found to be more prevalent to explain the recent increase in risk than the precautionary motive, since the importance of the precautionary motive has decreased over time. As a result, firms merely maintain little precautionary savings during the last decade (Boileau \& Moyen, 2009).

The decision of firms to hold significant cash reserves in recent times has received thoughtfulness in finance literature (Opler et al., 1999; Dittmar et al., 2002; Ozkan \& Ozkan, 2004). The static trade-off model suggested for this behavior implies that corporate cash holdings are there to achieve an 
INTERNATIONAL JOURNAL OF ACADEMIC RESEARCH IN BUSINESS AND SOCIAL SCIENCES Vol. 10, No. 8, 2020, E-ISSN: 2222-6990 @ 2020 HRMARS

optimal cash level with marginal revenue holding additional cash equal to marginal cost. If the appearance of an optimal cash level is true, then excessive or lower corporate cash relative to the optimal balance should have a negative contribution toward firm's performance. Theoretically, the estimation of optimal cash holdings is very easy to achieve, but not many firms maintain them in practical operations. The impact of excessive cash holdings on the performance of corporations can be either positive (Mikkelson \& Partch, 2003) or negative (Harford et al., 2008), subject to other factors such as governance and shareholders' protection.

Corporations with too much cash holdings are essentially generating more disadvantages than benefits on the business landscape, market, industry and economy. However, too little corporate cash holdings might cause a corporation to be trapped in liquidity difficulties with the high possibility of facing insolvency. In general, corporations with less cash holdings might fail to meet financial obligations from banks and creditors (suppliers). Once these corporations temporarily run out of cash, the scheduled debt claims and payments from corporations' payable parties will be postponed and delayed. The delayed payments will damage the corporations' reputation and trust of those payable parties that offer credit to the said corporations. Banks and suppliers may then evaluate corporations that are trapped in liquidity problems at a lower credit ranking as the result of losing trust in the financial condition of the said corporations. Subsequently, lower credit rankings could generate negative impacts on credit line availability and external financing costs. Banks may even charge higher interest on the credit offered to corporations with liquidity problems as the chances of default increase. Banks have to bear higher risks for the funds offered. Some banks might reject the application for external financing needs required by low-cash-holding corporations due to bad records in historical payment documentations. The same also applies to other alternative financial markets such as the stock and securities debt markets; higher fees will be charged for any external financial needs.

Liquidity problems will lead to additional fees involved in external financing as compensation for the higher risk tolerated by investors and banks, and the low-credit-ranking corporations. As a result of higher risks borne by the parties offering credit, suppliers may shorten the credit tenure offered to mitigate the risk taken, and set certain terms and conditions for repayment, which directly reduces the convenience and flexibility of the corporations. Some of the creditors and suppliers might transform the incremental risks into the price charged for raw materials and services offered, which then raises the total production cost and cost per unit produced. Corporations have to pay more for the same amount of raw materials and services whereas the selling price for each unit remains the same; because the increase in production cost is due to an internal problem, corporations are unable to transfer the burden to consumers. The increase in external finance fees and production cost might worsen the corporations' financial condition. This will then lead to more difficulty in accumulating cash.

Therefore, corporate cash holdings are significant in deciding the firms' performance and profitability, and also as an extension to shareholders' wealth. The matter of the amount of cash holdings in firms does not solely impact the firms' balance sheets and agency costs. It also has several effects on the different dimensions of credit ranking of firms, their reputations and investment opportunities, future development, and trust of their stakeholders.

The majority of studies of cash holdings were conducted in the institutionally more developed capital markets such as the United States, European countries and Japan. The main reason developed countries became the focus of these studies was due to the size of their markets, availability of 
information and the value of the research with more users interested in the findings (investors, stakeholders and number of firms). Therefore, studies of corporate cash holdings in developing capital markets are becoming increasingly importance, hence providing the motivation of the study, especially in new markets in the Asia-Pacific region. It is interesting to conduct research on AsiaPacific countries due to the heterogeneity of the regions' economies and their characteristics, which are recently having rapid growth. Therefore, this thesis, using appropriate methodology aims to examine the influence of cash holdings to firm's efficiency, and shareholders' valuation on cash per dollar.

As returns on investment and business fluctuation are unpredictable, firms would rather maintain a certain level of cash holdings than invest or expand their operations. Even though cash on hand is unproductive, it provides immediate liquidity to resolve any unexpected emergencies or losses. Cash holdings, agency cost and firm's performance are the usual elements shareholders are generally concerned with. Since shareholders are the owners of firms, their valuation with respect to the value of cash per dollar is also examined. From these findings, the perceptions of shareholders and managers towards cash can be revealed. Understanding the role of cash holdings aids in improving their utility as a workable tool in enhancing corporations' performance and maximizing their earnings. Soh et al (2018) conclude that higher cash holdings level able to enhance the firm's efficiency and production and profit generating. So, this paper aims to estimate the value of cash holdings and optimal cash levels through shareholders' valuation. The findings on this research issue will be able to reveal us the way shareholders judge the cash compared with the real way cash contributes to their wealth. Does the shareholders' valuation of cash per dollar reveal the role of cash holdings in generating firm earnings? If the answer is yes, then, theoretically, shareholders should be concerned about the optimal cash holding that reduces agency cost.

This study contributes to corporate financial policy and may enhance evidence on how shareholders' value cash holdings. Faulkender \& Wang (2006) investigated the deviation in the marginal value of corporate cash holdings from variances in corporate financial policies and showed that shareholders tend to judge a higher value for additional cash in a firm with low leverage and financial constraints. However, the role of cash holdings in generating a firm's efficiency has been largely ignored. This study provides supportive evidence on shareholder' valuation and agency conflict, by linking it to company efficiency which mentioned in Soh et al (2018). If the shareholder is aware of the role of cash holdings in generating a firm's efficiency, the value of cash can be adjusted according to cash levels. As shareholders tend to reduce agency conflict by reducing a firm's cash holdings, optimal cash holdings should not be overlooked during shareholders' valuation.

\section{Literature Review}

In a perfect market, the company must hold an additional dollar cash reserve equal to one dollar of the shareholder's valuation. However, due to the market operating under imperfect conditions, due to the information asymmetry between management and ownership units, the marginal value of shareholders' cash in various departments of the company will be significantly different. Shareholders who know that the company's cash balance is increasing and that most of the cash flows are anxious because they have no control over the company's cash holdings that the company manager decides to use. Bates et al. (2009) conducted the first study, explaining the increase in corporate cash holdings over the past three decades, and most of the existing literature provides additional evidence to support these factors that drive the company's cash holdings, mainly focus on 
mobility and preventive motivation. . Despite this, existing research largely ignores the role of shareholders in assessing the company's additional cash reserves. To date, there have been few studies on how shareholders measure excess cash reserves and the factors that influence their valuation of the dollar held in cash.

The grouping of samples provides interesting information for the shareholder valuation of each dollar of corporate cash reserves. For example, the size of the company is more reasonable for shareholders than for large companies; in addition, larger companies may involve more More agency costs. Faulkender \& Wang (2006) developed a regression model of excess stock returns for cash movements based on a set of independent variables. The regression coefficient reflects the shareholder's valuation of another dollar of cash holdings. The conditional version of the model allows cash estimates to respond with different time frames and different company characteristics. Bates et al. (2011) used the model of Faulkender \& Wang (2006) and concluded that the extra dollar cash value of small companies was: 1980s (\$0.69), 1990s (\$1.07) and 2000s (\$1.11); For larger companies: the 1980 s $(\$ 0.39)$, the 1990s (\$0.66), and the 2000s $(\$ 0.72)$. The results of these surveys show that the extra dollar cash value of small businesses is higher than that of large companies.

In addition, Pinkowitz Williamson's (2004) cash valuation found that shareholders with better growth options and more volatile investment opportunities have a higher value for corporate cash than those companies with less growth and stability. Their Dittmar \& Mahrt-Smith (2007) concluded that a poorly managed company would result in shareholders appraising additional cash at a lower interest rate. Other categories include countries with poor investor protection and stronger practices, as described by Pinkowitz et al. (2012), who wrote that the collection of investment opportunities has a better explanatory power than the company's financing opportunities that explain the value of shareholders' cash holdings. However, most of the research was conducted in the United States and developed countries; they did not focus on developing Asian countries to identify any major changes in the immature financial markets.

\section{Methodology}

\section{Data Sources and Variables}

The time period for this study began in 2006 and 2017. Due to the exclusive role of cash in the banking and finance industries, financial companies are not in the sample range. Mikkelson \& Partch (2003) considered cash holdings large when the ratio of a firm's cash-to-net assets is more than 25 per cent. However, their study does not provide an explanation on the reason why they set the 25 per cent cash to assets ratio as the clear cut in defining large cash-holding firms. Also, they did not show any evidence that their results will not change once the 25 per cent definition does not hold.

\section{Modeling}

The overall purpose of this section is to test the valuation effect of shareholder holdings of additional US dollars on high cash and low cash companies in different stock exchanges, with varying degrees of development. From the perspective of shareholders who are considered owners of the company, Pinkowitz \& Williamson (2004) used Fama \& French (1998) to study the marginal value of cash. He defined the dependent variable as the market value of the company's equity, indicating that their research is more realistic. There are few similar papers in the literature. May focus on the value of the company. 
INTERNATIONAL JOURNAL OF ACADEMIC RESEARCH IN BUSINESS AND SOCIAL SCIENCES Vol. 10, No. 8, 2020, E-ISSN: 2222-6990 @ 2020 HRMARS

This study seeks to estimate the expected stock returns slightly differently from the previous study, which used 25 Fama \& french portfolios formed on size and book-to-market ratios as the portfolio benchmark. Capital Asset Pricing Model (CAPM) is selected to calculate the expected stock return from the excess stock return estimation. The main difference between the expected stock return measurement using Fama \& french (1998)'s model against CAPM is the inclusion of idiosyncratic risk. CAPM expects that idiosyncratic risk will not be capable in carrying out any explanations on estimating the return rate of some stocks or portfolios. Certain literature show that the beta estimator will be unbiased if idiosyncratic risk is properly accounted for. However, the market factor is still the best factor to capture most variations in individual securities over time, comparatively with other identified factors or proxies. Furthermore, the portfolio returns might be affected by firm's idiosyncratic characteristics; the role of the market factor in asset pricing will then be underestimated. The conditional versions of both CAPM and the consumption of CAPM have been proven to accomplish significantly better results than their static counterparts in clarifying crosssectional variations in expected returns of size, and book-to-market ratios for arranged portfolios Therefore this study examines the reliability and accuracy of CAPM in estimating excess stock returns, compared with portfolio benchmark that was applied in previous studies. If the fitness of the model is similar for both methods, it indicates that the idiosyncratic risk does not carry any weight from the viewpoint of the shareholders' valuation.

In general, stock returns are affected by changes in common risk factors and company-specific characteristics. Given that company-specific risk factors have multiple characteristics and may be diversified, most asset pricing literature studies focus only on or focus on portfolio returns. However, since the importance of this paper is how the increase in the company's cash holdings affects the valuation of shareholders' holdings of cash, the individual's expected stock returns should be emphasized relative to the benchmark return of the portfolio.

Since the benefit of this goal is to examine how changes in equity value are associated with changes in the company's cash holdings, it is also important to include other relevant factors that affect cash holdings, which also have an impact on stock market value. As a result, excess equity returns are not only degraded as cash holdings change, but also with changes in corporate profitability, financing policies and investment policies. By assuming that the company has the same sensitivity to specific factors of these companies, the hypothesis can be tested by examining the coefficient differences of the subsamples. In the analysis process, the focus of this goal is the value of another dollar of cash, reflected by its coefficient and the coefficient associated with the interaction of other variables. All variables in this study depreciated with a one-year lag in stock market value to avoid the impact of firm size on outcomes and the dominance of large firms.

Following the baseline of the Faulkender \& Wang (2006) model and new cash-related variables, the estimation on the excess annual returns among cash holdings and other control variables will be separated into three models. The first model includes firm-specific variables, while the interaction effect of cash holdings and other particular variables are included in (3.2). In (3.3), a new variable named cash square is added in, in order to estimate the shareholders' valuation on the existence of optimal cash holdings. 
All variables in the regression use the same measurements of Faulkner \& Wang (2006), except the cash square. The findings in the mentioned study show that the coefficients of cash holdings, earnings, net assets, research and development (R\&D), dividends and lagged cash holdings are positively related to excess stock return. But, the coefficients of interest paid on debt, leverage, and two interaction variables related to cash holdings have a negative impact on excess stock return. Therefore, this study is expected to have similarly significant signs with the previous study.

The cash square is added in Model 3 in order to examine the view of shareholders on the optimal level of corporate cash holdings; also used in Martinez-Sola et al., (2011). The cash square, if statistically significant, is expected to be consistent with the findings in the previous study which show a negative relationship with excess stock returns. In other words, cash-holding levels that are too low will lead to a higher possibility of a firm turning illiquid, while too much cash holdings may cause agency conflict. As a result, any cash holdings beyond the level will decrease firm's value, subsequently delivering a lower valuation from shareholders. If this variable is significant, it indicates that shareholders do have concerns about the existence of an optimal cash level, and cash reserves beyond the optimal cash level should negatively affect stock price. Otherwise the role of the optimal cash level does not provide any explanation of shareholders' valuation, is less meaningful with regard to investors' considerations and analysis, and is not significant in influencing the stock price. The test model is tested for few diagnostic tests which required ensuring the reliability of panel regression result such as Heteroscedasticity, multicollinearity and autocorrelation.

Since the benefit of this goal is to examine how changes in equity value are associated with changes in the company's cash holdings, it is also important to include other relevant factors that affect cash holdings, which also have an impact on stock market value. As a result, excess equity returns are not only degraded as cash holdings change, but also with changes in corporate profitability, financing policies and investment policies. By assuming that the company has the same sensitivity to specific factors of these companies, the hypothesis can be tested by examining the coefficient differences of the subsamples. In the analysis process, the focus of this goal is the value of another dollar of cash, reflected by its coefficient and the coefficient associated with the interaction of other variables. All variables in this study depreciated with a one-year lag in stock market value to avoid the impact of firm size on outcomes and the dominance of large firms. The regression model is presented below: 
INTERNATIONAL JOURNAL OF ACADEMIC RESEARCH IN BUSINESS AND SOCIAL SCIENCES Vol. 10, No. 8, 2020, E-ISSN: 2222-6990 @ 2020 HRMARS

$$
\begin{aligned}
& r_{u}-R_{i}=\alpha_{0}+\alpha_{1} \frac{\Delta C_{i, t}}{M_{i, t-1}}+\alpha_{2} \frac{\Delta E_{i, t}}{M_{i, t-1}}+\alpha_{3} \frac{\Delta N A_{i, t}}{M_{i, t-1}}+\alpha_{4} \frac{\Delta R D_{i, t}}{M_{i, t-1}}+\alpha_{5} \frac{\Delta I_{i, t}}{M_{i, t-1}}+\alpha_{6} \frac{\Delta D_{i, t}}{M_{i, t-1}}+\alpha_{7} \frac{C_{i, t-1}}{M_{i, t-1}}+ \\
& \alpha_{8 L_{i, t}}+\varepsilon_{i, t} \\
& r_{u}-R^{2}=\beta_{0}+\beta_{1} \frac{\Delta C_{i, t}}{M_{i, t-1}}+\beta_{2} \frac{\Delta E_{i, t}}{M_{i, t-1}}+\beta_{3} \frac{\Delta N A_{i, t}}{M_{i, t-1}}+\beta_{4} \frac{\Delta R D_{i, t}}{M_{i, t-1}}+\beta_{5} \frac{\Delta I_{i, t}}{M_{i, t-1}}+\beta_{6} \frac{\Delta D_{i, t}}{M_{i, t-1}}+\beta_{7} \frac{c_{i, t-1}}{M_{i, t-1}}+ \\
& \beta_{8 L_{i, t}}+\beta_{9}\left(\frac{\Delta c_{i, t}}{M_{i, t-1}}\right)\left(\frac{c_{i, t-1}}{M_{i, t-1}}\right)+\beta_{10} \frac{\Delta c_{i, t}}{M_{i, t-1}} \times L_{i, t}+\varepsilon_{i, t} \\
& r_{u}-R^{\prime}=\gamma_{0}+\gamma_{1} \frac{\Delta C_{i, t}}{M_{i, t-1}}+\gamma_{2} \frac{\Delta E_{i, t}}{M_{i, t-1}}+\gamma_{3} \frac{\Delta N A_{i, t}}{M_{i, t-1}}+\gamma_{4} \frac{\Delta R D_{i, t}}{M_{i, t-1}}+\gamma_{5} \frac{\Delta I_{i, t}}{M_{i, t-1}}+\gamma_{6} \frac{\Delta D_{i, t}}{M_{i, t-1}}+\gamma_{7} \frac{c_{i, t-1}}{M_{i, t-1}}+ \\
& \gamma_{8 L_{i, t}}+\gamma_{9}\left(\frac{\Delta c_{i, t}}{M_{i, t-1}}\right)\left(\frac{c_{i, t-1}}{M_{i, t-1}}\right)+\gamma_{10} \frac{\Delta c_{i, t}}{M_{i, t-1}} \times L_{i, t}+\gamma_{11} \frac{c_{i, t}^{2}}{M_{i, t-1}}+\varepsilon_{i, t} \\
& r_{i, t}-R^{b}{ }_{i, t}: \quad \text { excess stock return, } \\
& r_{i, t} \quad: \quad \text { stock returns for firm } i \text { during accounting year } t \text {, } \\
& R_{i, t}^{b} \quad: \quad \text { stock } i \text { 's benchmark return at year } t \text {, } \\
& C_{i, t}: \quad \text { corporate cash holdings of firm } i \text { at time } t \text {, } \\
& I_{i, t} \quad: \quad \text { interest expenses, } \\
& D_{i, t} \quad: \quad \text { total dividends, } \\
& L_{i, t} \quad \text { : } \quad \text { market leverage at the end of accounting year } t \text {, } \\
& N F_{i, t} \text { : firm's net financing during accounting year } t \text {, } \\
& E_{i, t} \quad: \quad \text { earnings before interest and extraordinary items, } \\
& N A_{i} \text { : : total assets net of cash, } \\
& R D_{i, t}: \quad \mathrm{R} \& \mathrm{D} \text { expenditures, } \\
& M_{i, t-1}: \quad \text { one-year lagged stock market value, and }
\end{aligned}
$$

\section{Discussion}

\section{Descriptive Statistics for Shareholders' Valuation of Corporate Cash}

Table 4.1 provides a summary of descriptive statistics for shareholders' valuation for listed firms in Korea Exchange. These firm-specific variables cover significant variables in reflecting a firm's profitability, financing policy and investment policy. All variables except leverage, abnormal stock returns and cash square are deflated by the lagged market value of equity in order to remove the influence of varying firm sizes. The percentages of high-cash holding firms and low-cash holding firms are slightly different from the percentages shown in Table 4.2.1 due to the outlier trimming, and missing data. However, the percentages are very small, which are within +/- 0.2 per cent. The cash square is a bigger amount as it has not been estimated using the changes in years. All variables except cash square are less than one. 
INTERNATIONAL JOURNAL OF ACADEMIC RESEARCH IN BUSINESS AND SOCIAL SCIENCES Vol. 10, No. 8, 2020, E-ISSN: 2222-6990 @ 2020 HRMARS

Table 4.1: Descriptive statistics for Korea Exchange starting from 2006 to 2017

\begin{tabular}{|c|c|c|c|c|c|c|}
\hline \multirow{2}{*}{$\begin{array}{c}\text { Korea Exchange } \\
\text { Variable }\end{array}$} & \multicolumn{2}{|c|}{ All } & \multicolumn{2}{|c|}{ High-cash } & \multicolumn{2}{|c|}{ Low-cash } \\
\hline & Mean & Std. dev. & Mean & Std. dev. & Mean & Std. dev. \\
\hline$r_{h, t}-R_{i, t}$ & 0.3127 & 0.9305 & 0.3133 & 0.9492 & 0.3126 & 0.9277 \\
\hline$C^{2}$ & 166266 & 1874852 & 306287 & 2534476 & 145344 & 1754472 \\
\hline$\Delta C_{t}$ & 0.0419 & 0.3902 & 0.0656 & 0.3524 & 0.0383 & 0.3955 \\
\hline$\Delta D_{t}$ & 0.0044 & 0.0428 & 0.0057 & 0.0381 & 0.0043 & 0.0434 \\
\hline$\Delta E_{t}$ & 0.0765 & 0.543 & 0.0507 & 0.3355 & 0.0803 & 0.567 \\
\hline$\Delta I_{t}$ & 0.0074 & 0.0554 & 0.0019 & 0.0316 & 0.0081 & 0.0576 \\
\hline$C_{t=1}$ & 0.5672 & 1.2532 & 0.9322 & 1.8616 & 0.5138 & 1.1278 \\
\hline$L_{t}$ & 0.3416 & 0.2797 & 0.1155 & 0.1936 & 0.3754 & 0.2749 \\
\hline$\Delta N A_{t}$ & 0.5371 & 1.9162 & 0.2762 & 1.4523 & 0.5756 & 1.9727 \\
\hline$\Delta R D_{t}$ & 0.0057 & 0.0425 & 0.0051 & 0.0326 & 0.0058 & 0.0438 \\
\hline $\begin{array}{l}\text { No. of firms } \\
\text { Observation }\end{array}$ & \multicolumn{2}{|c|}{$\begin{array}{c}862(100 \%) \\
8026\end{array}$} & \multicolumn{2}{|c|}{$\begin{array}{c}92(10.67 \%) \\
941\end{array}$} & \multicolumn{2}{|c|}{$\begin{array}{c}770(89.32 \%) \\
7085\end{array}$} \\
\hline
\end{tabular}

Source: Datastream

The excess stock returns for listed firms in Korea Exchange show a positive sign with 0.3127. Overall, the stock market in Korea Exchange over the past 10 years is growing. The stock market in Korea also has a higher risk, reflected by the relatively higher standard deviation of 0.9305 . Firms with more volatile market-to-book ratios tend to have larger cash balances, and they are also more likely to have excess cash (Maria et al., 2013).

High-cash holding firms have higher cash square than low-cash holding firms in both stock exchanges. The standard deviations for the cash square of high-cash holding firms are very much higher than those of low-cash holding firms. High-cash holding firms have higher lagged cash, change in cash and dividend payout, whereas low-cash holding firms have higher leverage, change in interest expenses, net assets and R\&D expenses. Low-cash holding firms in Korea Exchange have the higher change in earnings than high-cash holding firms. Firms with more corporate cash tend to distribute higher dividends. Firms with high payout ratios are more likely to have ample internal funds to cover their debt obligations and to finance their investments. Thus the leverage of high-cash holding firms is lower, dissimilar from some literature. However, some studies show that firms can retain financial flexibility by holding large cash reserves and remaining in low debt/leverage situations, suggesting a negative relationship between firms' cash reserves and leverage (Graham \& Harvey, 2001). Firms with high-cash can pay back all of its debt obligations with its cash holdings (Bates et al., 2009). Moreover, high-cash holding firms tend to spend less on interest expenses as they have sufficient internal funds to run their daily transactions and meet some of their investment needs. Therefore, the table reports higher interest expenses for low-cash holding firms.

The results of the Korea Exchange are shown in Table 4.2. The cash square variable is added to test for the shareholders' valuation on the existence of optimum cash holdings. Many researchers argue the importance of optimum cash in firm's performance. Yet the optimum cash level is very difficult to identify; no studies have examined the optimum cash holdings from the valuation of the shareholders. Therefore, having included the effect of the cash square, the estimation on the 
INTERNATIONAL JOURNAL OF ACADEMIC RESEARCH IN BUSINESS AND SOCIAL SCIENCES Vol. 10, No. 8, 2020, E-ISSN: 2222-6990 @ 2020 HRMARS

marginal additional dollar of cash could be more interesting. The results in pooled data show that the coefficient for optimal cash is less than 0.0000 and insignificant at less than 1 per cent. In other words, shareholders are less likely to be concerned about the existence of an optimal cash holdings level relative to other variables related to a firm's profitability, financial policy and investment policy. The presence of optimum cash fails to contribute any additional value to share prices. This suggests that the focus of the firm's operational management is different from that of the shareholders' valuation; certain things may not carry the same weight for the shareholders as their interest in the business is not the same.

This study further analysis the shareholders' valuation of the marginal dollar of cash by separating the listed firms of Korea Exchange into high-cash holding firms and low-cash holding firms. A high value of cash will contribute to smaller firms in terms of greater firm growth, and assisting with financial constraints, higher payout ratios, and lower interest coverage. As presented in the descriptive statistics table, high-cash holding firms in Korea Exchange are having higher growth rate (as shown in Table 4.1), higher dividend payout and lower interest expenses. Such effects would likely be incorporated into firm's value of dollar cash. Therefore, it is expected that high-cash holding firms will have a higher margin of extra dollar cash due to lower chances of being in default, whereas lowcash holding firms might accrue some of the additional cash holdings into debt and financial expenses on external funding, with a higher probability of turning illiquid.

High-cash holding firms should have less leverage as they are able to finance the cash needed by their existing levels of cash on hand. Therefore, the impact of debt on the additional cash holdings will carry greater weight while estimating the value of the extra dollar cash held, as valued by shareholders. Besides, high existing cash on hand also reduces the value of additional dollar cash as the existing liquidity is sufficient for daily operations; extra cash holdings are more likely to suffer from agency conflict as described by Jensen (1986). Managers have 
INTERNATIONAL JOURNAL OF ACADEMIC RESEARCH IN BUSINESS AND SOCIAL SCIENCES Vol. 10, No. 8, 2020, E-ISSN: 2222-6990 @ 2020 HRMARS

Table 4.2: Shareholders' valuation for listed firms in Korea Exchange starting from 2006 to 2017

\begin{tabular}{|c|c|c|c|}
\hline Variable & Model 1 & Model 2 & Model 3 \\
\hline & 0.6660 & 0.6454 & 0.6448 \\
\hline \multirow[t]{2}{*}{ Constant } & {$[5.8400 * * *]$} & {$[5.9000 * * *]$} & {$[5.8700 * *]$} \\
\hline & $(0.0000)$ & $(0.0000)$ & $(0.0000)$ \\
\hline \multirow{3}{*}{$\Delta I_{\mathrm{t}}$} & -0.7525 & -0.6881 & -0.6840 \\
\hline & {$[-2.7900 * *]$} & {$[-2.6200 * *]$} & {$[-2.6100 * *]$} \\
\hline & $(0.0050)$ & $(0.0090)$ & $(0.0090)$ \\
\hline \multirow{3}{*}{$L_{t}$} & -1.5716 & -1.5244 & -1.5241 \\
\hline & {$[-6.2000 * * *]$} & {$[-6.5900 * * *]$} & {$[-6.6100 * * *]$} \\
\hline & $(0.0000)$ & $(0.0000)$ & $(0.0000)$ \\
\hline \multirow{3}{*}{$\Delta N A_{t}$} & 0.0665 & 0.0547 & 0.0541 \\
\hline & {$[6.3600 * * *]$} & {$[5.7800 * * *]$} & {$[5.7100 * * *]$} \\
\hline & $(0.0000)$ & $(0.0000)$ & $(0.0000)$ \\
\hline \multirow{3}{*}{$\Delta E_{\mathrm{t}}$} & 0.1952 & 0.2319 & 0.2324 \\
\hline & {$[4.7900 * * *]$} & {$[5.1100 * * *]$} & {$[5.1400 * * *]$} \\
\hline & $(0.0000)$ & $(0.0000)$ & $(0.0000)$ \\
\hline \multirow{3}{*}{$\Delta D_{t}$} & 0.9530 & 0.7641 & 0.7735 \\
\hline & {$[1.9600 * *]$} & {$\left[1.6600^{*}\right]$} & [1.6800*] \\
\hline & $(0.0500)$ & $(0.0980)$ & $(0.0930)$ \\
\hline \multirow{3}{*}{$\Delta R D_{t}$} & 1.3276 & 1.5652 & 1.5746 \\
\hline & {$[2.5600 * *]$} & {$[3.0100 * *]$} & {$[3.0200 * *]$} \\
\hline & (0.0110) & $(0.0030)$ & $(0.0030)$ \\
\hline \multirow{3}{*}{$\Delta C_{t}$} & 0.4976 & 0.9096 & 0.9008 \\
\hline & {$[3.5500 * * *]$} & {$[4.3700 * * *]$} & {$[4.2900 * * *]$} \\
\hline & $(0.0000)$ & $(0.0000)$ & $(0.0000)$ \\
\hline \multirow{3}{*}{$c_{t-1}$} & 0.1408 & 0.3717 & 0.3678 \\
\hline & {$[6.2600 * * *]$} & {$[5.5700 * * *]$} & {$[5.5000 * * *]$} \\
\hline & $(0.0000)$ & $(0.0000)$ & $(0.0000)$ \\
\hline \multirow{3}{*}{$\Delta C_{t} * L_{t}$} & & -0.1653 & -0.1666 \\
\hline & & {$[-2.1600 * *]$} & {$[-2.1900 * *]$} \\
\hline & & $(0.0310)$ & $(0.0290)$ \\
\hline \multirow{3}{*}{$\Delta C_{\mathrm{t}} * C_{\mathrm{t}-1}$} & & -0.1989 & -0.1974 \\
\hline & & {$[-4.1000 * * *]$} & {$[-4.0400 * * *]$} \\
\hline & & $(0.0000)$ & $(0.0000)$ \\
\hline \multirow{3}{*}{$C^{2}$} & & & 0.0000 \\
\hline & & & [1.1200] \\
\hline & & & $(0.2630)$ \\
\hline Ad R-square & 0.1827 & 0.1857 & 0.1863 \\
\hline F-stat/ chi-square & 46.4700 & 35.2300 & 33.1500 \\
\hline$p$-value & $(0.0000 * * *)$ & $(0.0000 * * *)$ & $(0.0000 * * *)$ \\
\hline
\end{tabular}

Significant at $0.01\left(^{*}\right), 0.05\left(^{* *}\right), 0.001\left(^{* *}\right)$ level, $\mathrm{t}$-values are in square brackets, $\mathrm{p}$-values are in parentheses. 
INTERNATIONAL JOURNAL OF ACADEMIC RESEARCH IN BUSINESS AND SOCIAL SCIENCES Vol. 10, No. 8, 2020, E-ISSN: 2222-6990 @ 2020 HRMARS

Reasons to increase the total cash under their control as it enables them to spend it for their personal interests, for example, via spendthrift funds by consuming privileges, or making unproductive investment decisions. With firms holding high levels of cash, the flexibility of high liquid assets might be used to serve the personal interests of the management team, which will increase the chances of a firm turning into default. Therefore, the higher coefficients of the two interaction variables related with cash for high-cash holding firms show that the presence of existing cash on hand and leverage does further reduce the value of additional dollar cash in the view of the shareholders.

Surprisingly, the cash square is significant at 0.01 . However, the coefficient is too small, which is less than 0.000 . Thus the impact of optimum cash is very limited or has relatively no impact on the valuation.

For low-cash firm, the interaction between marginal additional dollar cash and cash on hand reduces the valuation on cash per dollar as well. Low-cash holding firms with 10 per cent more cash on hand will decrease the additional cash at 2.464 per cent. Since it is more logical that low-cash holding firms increase additional cash, shareholders' values for $\left(^{*}\right)$ and $\left(^{*}\right)$ are lower compared with high-cash holding firms. As usual, the cash square for low cash firm is not significant. The F-statistic for all the models is significant at 0.001 and the adjusted R-square of the model is within the range of 0.1957 to 0.1992 .

\section{Conclusion}

This paper is to estimate the valuation of shareholders of the value of additional cash holdings and the existence of an optimal cash level. Previous studies estimated excess stock returns using the Fama \& French (1998) portfolio benchmark. This study employs dissimilar methods in estimating the excess stock return, where the expected return estimation uses the CAPM model with the belief that market factor is still the best factor that captures most of the variations in individual securities over time comparatively with other identified factors or proxies. The comparison of the reliability and fitness of model is conducted in order to liken the accuracy of the different expected return estimations. In this study, the shareholders' valuation model includes a new variable (cash square) that reflects the value of optimal cash levels in the view of shareholders. The value of additional cash is influenced by the cash on hand and interactions among lagged cash and leverage. Shareholders expect higher dividend payments from high-cash holding firms. The value of additional cash holdings is higher for high-cash holding firms than for low-cash holding firms. This shows that the shareholders do include the efficiency generated by cash holdings into their valuation (which presented by higher mean of firm's efficiency for high-cash holding firms). In other words, firms with higher cash would generate higher excess stock returns. The shareholders' valuation does not tally with agency cost, showing that shareholders prefer firms to hold less cash. Furthermore, the optimal cash level is not significantly related with shareholders' valuation.

\section{References}

Acharya, V. V., \& Johnson, T. (2007). Cash-in-the-market pricing and optimal resolution of bank failures. Bank of England working papers, 328.

Acharya, V. V., Davydenko, S. A., \& Strebulaev, A. A. (2011). Cash holdings and credit risk. NBER Working paper no. 16995. 
INTERNATIONAL JOURNAL OF ACADEMIC RESEARCH IN BUSINESS AND SOCIAL SCIENCES

Vol. 10, No. 8, 2020, E-ISSN: 2222-6990 @ 2020 HRMARS

Dittmar, A., Mahrt-Smith, J., \& Servaes, H. (2002). International corportae governance and corrporate cash holdings. Journal of Financial and Quantitative Analysis.

Dittmar, Amy, \& Mahrt-Smith, J. (2007), Corporate governance and the value of cash holdings, Journal of Financial Economics. 83, 599-634.

Fama, E. F., \& Kenneth, R. F. (1998). Value Versus Growth: The International Evidence. Journal of Finance, 53:6, pp. 1975-999.

Faulkender, M., \& Wang, R. (2006). Corporate financial policy and the value of cash. The Journal of Finance, 4, 1957 - 1990.

Guney, Y., Ozkan, A., \& Ozkan, N. (2006). International evidence on the non-linear impact of leverage on corporate cash holdings. Journal of Multinational Financial Management 17, Available at SSRN: http://ssrn.com/abstract=1517110.

Hall, B. H. (1987). The relationship between firm size and firm growth in the US manufacturing sector. Journal of Industrial Economics, 35 (4), 583 - 596.

Hanazaki, M., \& Liu, Q. (2007). Corporate governance and investment in East Asian firms-empirical analysis of family-controlled firms. Journal of Asian Economics, 18, 76 - 97.

Harford, J. (1999). Corporate cash reserves and acquisitions. Journal of Finance, 54, 1969-1997.

Harford, J., Mansi, S. A., \& Maxwell, W. F. (2008). Corporate Governance and Firm Cash Holdings in the US. Journal of Financial Economics, 87, 535-555.

Jensen, M. C. (1986). Agency costs of free cash flow, corporate finance and takeovers. American Economic Review, 76, 323-39.

Kalcheva, I., \& Lins, K. V. (2007). International evidence on cash holdings and expected managerial agency problems. The Review of Financial Studies, volume 20, no. 4, 1087-1112.

Lau, J., \& Block, J. H. (2012), "Corporate cash holdings and their implications on firm value in family and founder firms", Corporate Ownership and Control, 1-40, available at: http://ssrn.com/abstract $1 / 42000175$

Mikkelson, W. H., \& Partch, M. M. (2003). Do persistent large cash reserve hinder performance? Journal of Financial and Quantitative Analysis, 38, 275-294.

Miller, K. D. (1992). A Framework for Integrated Risk Management in International Business, Journal of International Business Studies, Vol. 23, No. 2, 311-331.

Opler, T., Pinkowitz, L., Stulz, R., \& Williamson, R. (2001). Corporate cash holdings. Journal of Applied Corporate Finance, Volume 14, pages 55-67.

Ozkan, A., Ozkan, N. (2004). Corporate cash holdings: an empirical investigation of UK companies. Journal of Banking and Finance 28, 2103-2134.

Ozkan, A., \& Ozkan, N. (2004). Corporate cash holdings: an empirical investigation of UK companies. Journal of banking \& Finance 36, Volume 28, (Issue: 09,), 2103-2134.

Stulz, A. (1990). Managerial discretion and optimal financing policies. Journal of financial Economics 26, pages 3-27.

White, H. (1980). A Heteroskedasticity-Consistent Covariance Matrix Estimator and a Direct Test for Heteroskedasticity. Econometrica, 48, 817-838.

Soh, W. N., Nassir, A. M. D., \& Cheng, F. F. (2018). Cash and Profit Efficient in Malaysia and South Korea Listed Company using Non-parametric and Parametric Regression Method. International Journal of Economics and Management. 12 (S2), 711-729. 